\section{Analysis of Michigan Full-service Retail Florist Businesses by Annual Gross Sales}

\author{
Carolyn A. Collins ${ }^{1}$ and Barbara Fails \\ Department of Horticulture, Michigan State University, East Lansing, \\ MI 48824-1325
}

Oliver Schabenberger

Department of Crop and Soil Sciences, Michigan State University, East Lansing, MI 48824-1325

Additional index words. floriculture, marketing, management, floral industry, wages, finances, delivery service, survey

Abstract. Comprehensive industry statistics are valuable tools for small business owners and managers. The traditional full-service retail florist competes with supermarkets, limited-service flower shops, corner vendors, and telemarketing, catalog, and Internet firms. Although some retail florist business information does exist on a national basis, none specifically addresses Michigan florists. In Mar. 1996, a comprehensive mail survey of Michigan full-service retail florists was conducted with the cooperation of the Michigan Floral Association. The survey focused on 1995 general business operations, delivery services, advertising and marketing practices, staffing and wages, and financial status. Statistical analyses showed total wage expenses and occupancy costs to be major factors controlling net profits. The cost of delivery service and wire service membership also affected profitability. Full-service retail florists must examine and modify the cost structure of their businesses to generate the highest possible net profits.

Business statistics are meaningful and valuable tools for business owners and industry researchers alike. Most information is collected by private organizations, and therefore is not in the public domain for other businesses to utilize as benchmarks. The majority of research within the retail florist industry targets consumers or markets, not business practices. Wire service surveys have been the primary source of business data for floral retailers, notably the FTD Flower Business Fact Book (Florists' Transworld Delivery Association, 1991), the AFS “Annual Wage Survey" presented in Floral Finance (American Floral Services, 1996), and the annual "Floral Industry Trends" article presented in Teleflora's Flowers\& (Teleflora, 1996). The last nonpartisan study of retail florist business practices, Business Analysis of Pennsylvania Retail Florists (Voigt, 1977), was conducted in 1977. This study surveyed 47 Pennsylvania retail florists to determine costs of goods sold, gross profit, operating expenses, employee wages, and a number of qualitative factors, such as family influences on business operations.

Received for publication 19 June 1997. Accepted for publication 22 June 1998. The cost of publishing this paper was defrayed in part by the payment of page charges. Under postal regulations, this paper therefore must be hereby marked advertisement solely to indicate this fact.

${ }^{1}$ Current address: 3465 W. 13th Street, Yuma, AZ 85364.
Focus group studies conducted by the Michigan Floral Association indicated a demand for comprehensive business statistics. Limited retail florist business information does exist on a national basis, but none specifically addresses Michigan retail florists. The objectives of this research were to identify business factors that best describe the Michigan, fullservice retail florist businesses within annual gross sales categories, and determine selected predictors for profitability.

\section{Materials and Methods}

A survey was developed and tested to obtain 1995 statistical information on general business operations, delivery services, advertising and marketing practices, staffing and wages, and financial circumstances. Ques- tions were tailored to facilitate data analysis. Survey construction and implementation followed the Total Design Method (Dillman 1978). Validity and reliability of the survey were checked with two focus group studies, the first by members of the Board of Directors of the Michigan Floral Association, and the second by a representative group of floral retailers from Lansing, Mich. Questions were modified to reduce ambiguity following each assessment.

The initial target population for the survey was all cut flower retailers in Michigan, although only selected results from independently owned, full-service retail florists are presented here. The mailing sample was constructed from a compilation of the Michigan Floral Association's mailing list and the Michigan Business Directory (American Business Directories, 1995). To better target the cut flower retailer population in Michigan, the compilation was reduced to 1508 listings by the removal of any business name that did not include one of these words or some variation of them: flower, floral, florist, bloom, bouquet, centerpiece, blossom, petals. The following exceptions applied: all supermarkets were retained, as was any business not complying with the name criteria, but known to sell cut flowers at retail; however, businesses known to be wholesale only, dried/artificial flowers only, or greenhouse/garden centers only, were removed from the list. The final mailing list still contained nine different business descriptions (Table 1).

Announcement cards were mailed on 19 Feb. 1996 to inform businesses of the upcoming survey and the types of information requested. The surveys were mailed 2 weeks later, along with a cover letter and a postagepaid reply envelope. Reminder postcards were sent to nonrespondents on 2 May 1996. The deadline for the return of the surveys was 15 May 1996. Businesses that returned surveys were rewarded with a complimentary copy of the Michigan Floral Retailer Business Report (Collins and Fails, 1996).

Each survey was imprinted with a code number corresponding to its region and position on the mailing list. Code numbers were used to keep track of the returned surveys for complimentary report mailing and to prevent reminder letters from being sent to those busi-

Table 1. Number of responses, categorized by business description.

\begin{tabular}{lc}
\hline Business description & Number of responses \\
\hline $\begin{array}{l}\text { Independently owned, full-service retail flower shop } \quad \text { (wire services and delivery) } \\
\text { Independently owned, limited-service flower shop } \\
\quad \text { (no wire service and/or no delivery) }\end{array}$ & 183 \\
Combination florist and greenhouse or florist and garden center & 7 \\
Supermarket floral department & 37 \\
Retail greenhouse or garden center only & 4 \\
Dried and/or artificial flowers only & 3 \\
Special events or rental company & 7 \\
Floral franchise & 3 \\
Gift and/or novelty store & 2 \\
No response given & 2 \\
Total & 2 \\
\hline
\end{tabular}


nesses that had already returned surveys.

Two hundred and fifty responses were received across all nine business descriptions out of the 1508 surveys mailed, although two of the nine business descriptions accounted for $88 \%$ of the total responses (Table 1). This is sufficient to provide confidence estimates with $5 \%$ precision and $90 \%$ coverage probability for most variables when considering all business descriptions together. Similar confidence for the stratum of the 183 full-service retail florist respondents analyzed here is reasonable to expect, although verification is precluded by not knowing the actual number of full-service retail florists who received a survey.

The 183 full-service retail florist respondents were post-stratified in annual gross sales categories to homogenize sample size per category. Mean values were determined for each question in the survey by annual gross sales category. Differences between the category means were determined by analysis of variance methods, excluding responses with missing information for particular variables on an analysis-by-analysis basis. This causes slight variation in the effective sample size for each analysis. Tukey's HSD at $P \leq 0.10$ was used for mean comparisons. Standard regression procedures were performed on selected variables with respect to annual gross sales.

\section{Results and Discussion}

Survey results for full-service retail florists were divided into annual gross sales categories to facilitate the determination of variables having the greatest impact on a business's profitability. These annual gross sales categories and the number of respondents in each category were: low $(\$ 100,000-199,999)$ with 44 respondents, middle (\$200,000-399,999) with 42 respondents, and high $(\$ 400,000$ and over) with 39 respondents. Those 58 respondents reporting annual gross sales $<\$ 100,000$ were excluded from this analysis because they were not full-time, self-sustaining businesses offering both delivery and wire service, and many operated out of a home.

Delivery. The average delivery radius, delivery fee, and percentage of sales delivered did not differ significantly among the annual gross sales categories (Table 2). There appeared, however, to be an increase in delivery fees with increasing annual gross sales. The average retail price of a delivered package increased similarly as annual gross sales increased, with the price significantly greater if annual gross sales exceeded $\$ 200,000$. The trend in cost per delivery was not monotonic in annual gross sales. Businesses in the lowest annual gross sales category exhibited significantly higher costs per delivery $(\$ 5.88)$ than those in the two higher annual gross sales categories (\$3.49 middle, \$4.08 high). Businesses in all annual gross sales categories failed to recover delivery costs through the associated fee. Evaluation of a business's delivery service is necessary to establish appropriate fees and to control costs (Collins and Fails, 1997).
Staffing and wages. Businesses in the lower two annual gross sales categories were owned by an average of 1.1 and 1.3 full-time equivalent(FTE) individuals respectively, while businesses in the higher annual gross sales category were owned by 1.9 FTE individuals (Table 3). As gross sales increased, average salary per owner increased $48.2 \%$. Although the tendency for employee hourly wages to increase with annual gross sales was not statistically significant (Tables 3 and 4), it may have some economic significance. Average 1995 Michigan hourly wages for owners and managers of $\$ 11.45$ and $\$ 9.51$, respectively, (Collins and Fails, 1996) were lower than the national averages of $\$ 14.29$ and $\$ 11.93$ reported in Floral Finance (American Floral Services, 1996). Michigan floral designers, office staff, delivery staff, and salespeople were paid approximately the same hourly wage (\$7.62, \$7.31, \$5.95, \$5.86, respectively) as

Table 2. Comparison of mean full-service retail florist delivery services by annual gross sales category.

\begin{tabular}{lccr}
\hline \hline & \multicolumn{3}{c}{ Annual gross sales category } \\
\cline { 2 - 4 } Variable & $\$ 100,000$ to & $\$ 200,000$ to & $\$ 400,000$ \\
Percentage of sales delivered & $\$ 199,999$ & $\$ 399,999$ & and higher \\
Delivery radius (km from store) & $68.5 \mathrm{a}^{\mathrm{z}}$ & $70.1 \mathrm{a}$ & $64.6 \mathrm{a}$ \\
Delivery fee & $9.1 \mathrm{a}$ & $7.8 \mathrm{a}$ & $10.0 \mathrm{a}$ \\
Retail price of a delivered package & $\$ 3.23 \mathrm{a}$ & $\$ 3.44 \mathrm{a}$ & $\$ 3.76 \mathrm{a}$ \\
Cost per delivery & $\$ 26.86 \mathrm{~b}$ & $\$ 29.99 \mathrm{a}$ & $\$ 32.31 \mathrm{a}$ \\
\hline
\end{tabular}

${ }^{\mathrm{z}}$ Mean separation within variables by Tukey's HSD, $P \leq 0.10$.

Table 3. Comparison of mean full-service retail florist owner and manager staffing and wages by annual gross sales category.

\begin{tabular}{lccc}
\hline \hline & \multicolumn{3}{c}{ Annual gross sales category } \\
\cline { 2 - 4 } Variable & $\$ 100,000$ to & $\$ 200,000$ to & $\$ 400,000$ \\
and higher
\end{tabular}

${ }^{\mathrm{z}} \mathrm{FTE}$ : full-time equivalent.

${ }^{y}$ Mean separation within variables by Tukey's HSD, $P \leq 0.10$.

Table 4. Comparison of mean full-service retail florist staffing and wages by annual sales category.

\begin{tabular}{|c|c|c|c|}
\hline \multirow[b]{2}{*}{ Variable } & \multicolumn{3}{|c|}{ Annual gross sales category } \\
\hline & $\begin{array}{l}\$ 100,000 \text { to } \\
\$ 199,999\end{array}$ & $\begin{array}{l}\$ 200,000 \text { to } \\
\$ 399,999\end{array}$ & $\begin{array}{l}\$ 400,000 \\
\text { and higher }\end{array}$ \\
\hline$\overline{\text { FTE }^{\mathrm{z}} \text { floral designers }}$ & $1.1 \mathrm{~b}^{\mathrm{y}}$ & $2.0 \mathrm{~b}$ & $4.4 \mathrm{a}$ \\
\hline Floral designer hourly wage & $\$ 7.52 \mathrm{a}$ & $\$ 7.62 \mathrm{a}$ & $\$ 8.32 \mathrm{a}$ \\
\hline $\begin{array}{l}\text { Annual gross sales of arrangements } \\
\text { per FTE designer }\end{array}$ & $\$ 74,289$ a & $\$ 82,088 \mathrm{a}$ & $\$ 115,879 \mathrm{a}$ \\
\hline FTE sales staff & $0.8 \mathrm{~b}$ & $1.0 \mathrm{~b}$ & $3.2 \mathrm{a}$ \\
\hline Sales staff hourly wage & $\$ 5.69 \mathrm{~b}$ & $\$ 5.50 \mathrm{~b}$ & $\$ 6.34 \mathrm{a}$ \\
\hline $\begin{array}{l}\text { Total annual gross sales } \\
\text { per FTE salesperson }\end{array}$ & $\$ 128,191 \mathrm{~b}$ & $\$ 250,717 \mathrm{~b}$ & $\$ 392,963$ a \\
\hline FTE office staff & $0.2 \mathrm{~b}$ & $0.3 \mathrm{~b}$ & $1.2 \mathrm{a}$ \\
\hline Office staff hourly wage & $\$ 5.46 \mathrm{~b}$ & $\$ 6.59 \mathrm{~b}$ & $\$ 8.58 \mathrm{a}$ \\
\hline FTE delivery drivers & $0.9 \mathrm{~b}$ & $0.9 \mathrm{~b}$ & $2.2 \mathrm{a}$ \\
\hline Delivery driver hourly wage & $\$ 5.20 \mathrm{~b}$ & $\$ 5.82 \mathrm{~b}$ & $\$ 6.66 \mathrm{a}$ \\
\hline $\begin{array}{l}\text { Delivered annual gross sales } \\
\text { per FTE delivery driver }\end{array}$ & $\$ 117,480 \mathrm{~b}$ & $\$ 259,687 \mathrm{a}$ & $\$ 294,287$ a \\
\hline $\begin{array}{l}\text { Annual gross sales generated } \\
\text { per dollar of wage expense }\end{array}$ & $\$ 5.45 \mathrm{a}$ & $\$ 4.01 \mathrm{~b}$ & $\$ 3.47 \mathrm{~b}$ \\
\hline
\end{tabular}

${ }^{2}$ FTE: full-time equivalent

yMean separation within variables by Tukey's HSD, $P \leq 0.10$. 
employee figures showed that the manner in which the respondents categorized their employees had a definite effect on the mean response to this question. For instance, an employee categorized as a floral designer may actually spend only $75 \%$ of the time designing and $25 \%$ of the time handling sales. This ambiguity in employee job responsibilities should be noted when examining these figures.

Products and services sold. Products and services sold, expressed as a percentage of annual gross sales, did not differ statistically among the three annual gross sales categories (Table 5). One exception was the mathematical difference between outgoing and incoming wire orders. A customer who wants to send flowers to a distant location contacts a local (sending) florist to transmit the outgoing wire order through a wire service to the distant (receiving) florist, who then fills the incoming wire order per the customer's instructions. Generally, sending stores (outgoing wire orders) earn $20 \%$ commission on all wire orders (Redbook Floral Services, 1994). The wire service retains $7 \%$ of the purchase value. Receiving stores (incoming wire orders) fill the orders at $100 \%$ of the purchase value, but are rebated only $73 \%$ of that value by the wire service. Businesses with more outgoing than incoming orders have lower direct costs associated with wire services, and therefore tend to be more profitable. For businesses in the two lower annual gross sales categories, the outgoing minus incoming wire orders figures were $-2.9 \%$ and $-0.3 \%$, respectively, i.e., they had more incoming than outgoing wire orders. Businesses in the highest annual gross sales category had significantly more outgoing than incoming orders (3.8\%). Regression showed a significant quadratic relationship $(P=0.03)$, with outgoing and incoming wire orders, expressed as a percentage of sales, approximately equal at $\$ 407,000$ annual gross sales (Fig. 1A). However, the net cost to businesses at the $\$ 407,000$ annual gross sales level is still the wire service commission (customarily $7 \%$ ). The correlation coefficient, although significant, was rather low because of the large variability in the differences between outgoing and incoming wire orders for a given annual gross sales figure.

Those businesses that receive more incoming orders than they send are possibly losing a considerable amount of money and adversely affecting their net profits. There are numerous sending-only services in operation today. Telemarketing and Internet firms like 1-800 Flowers and FTD Online make it difficult for receiving florists to break even on wire service orders. These sending-only wire services are keeping not only the standard $7 \%$ fee, but also the $20 \%$ sending commission.

Business expenses and net profits. Cost of goods sold (COGS) and advertising expenses were not significantly different for businesses in any of the annual gross sales categories (Table 6). Cost of goods sold has long been considered a factor controlling retail florist business profitability, but our findings suggest that COGS is not as important as is commonly thought.
Table 5. Comparison of mean full-service retail florist products and services sold by annual sales category (expressed as a percentage of annual gross sales).

\begin{tabular}{lccr}
\hline \hline & \multicolumn{3}{c}{ Annual gross sales category } \\
\cline { 2 - 4 } Variable & $\$ 100,000$ to & $\$ 200,000$ to & $\begin{array}{c}\$ 400,000 \\
\text { and higher }\end{array}$ \\
\hline Fresh cut flowers—-by stem or bunch & $12.4 \mathrm{a}^{\mathrm{z}}$ & $12.9 \mathrm{a}$ & $13.0 \mathrm{a}$ \\
Fresh cut flowers—arranged & $35.9 \mathrm{a}$ & $35.6 \mathrm{a}$ & $35.0 \mathrm{a}$ \\
Plants & $14.6 \mathrm{a}$ & $13.7 \mathrm{a}$ & $12.9 \mathrm{a}$ \\
Dried and silk arrangements & $8.0 \mathrm{a}$ & $6.6 \mathrm{a}$ & $5.7 \mathrm{a}$ \\
Gift items & $6.8 \mathrm{a}$ & $6.3 \mathrm{a}$ & $8.7 \mathrm{a}$ \\
Service & $3.6 \mathrm{a}$ & $4.4 \mathrm{a}$ & $5.6 \mathrm{a}$ \\
Outgoing wire orders & $8.8 \mathrm{a}$ & $10.6 \mathrm{a}$ & $11.1 \mathrm{a}$ \\
Incoming wire orders & $11.7 \mathrm{a}$ & $10.9 \mathrm{a}$ & $7.3 \mathrm{a}$ \\
Outgoing minus incoming wire orders & $-2.9 \mathrm{~b}$ & $-0.3 \mathrm{ab}$ & $3.8 \mathrm{a}$ \\
\hline
\end{tabular}

${ }^{2}$ Mean separation within variables by Tukey's HSD, $P \leq 0.10$.
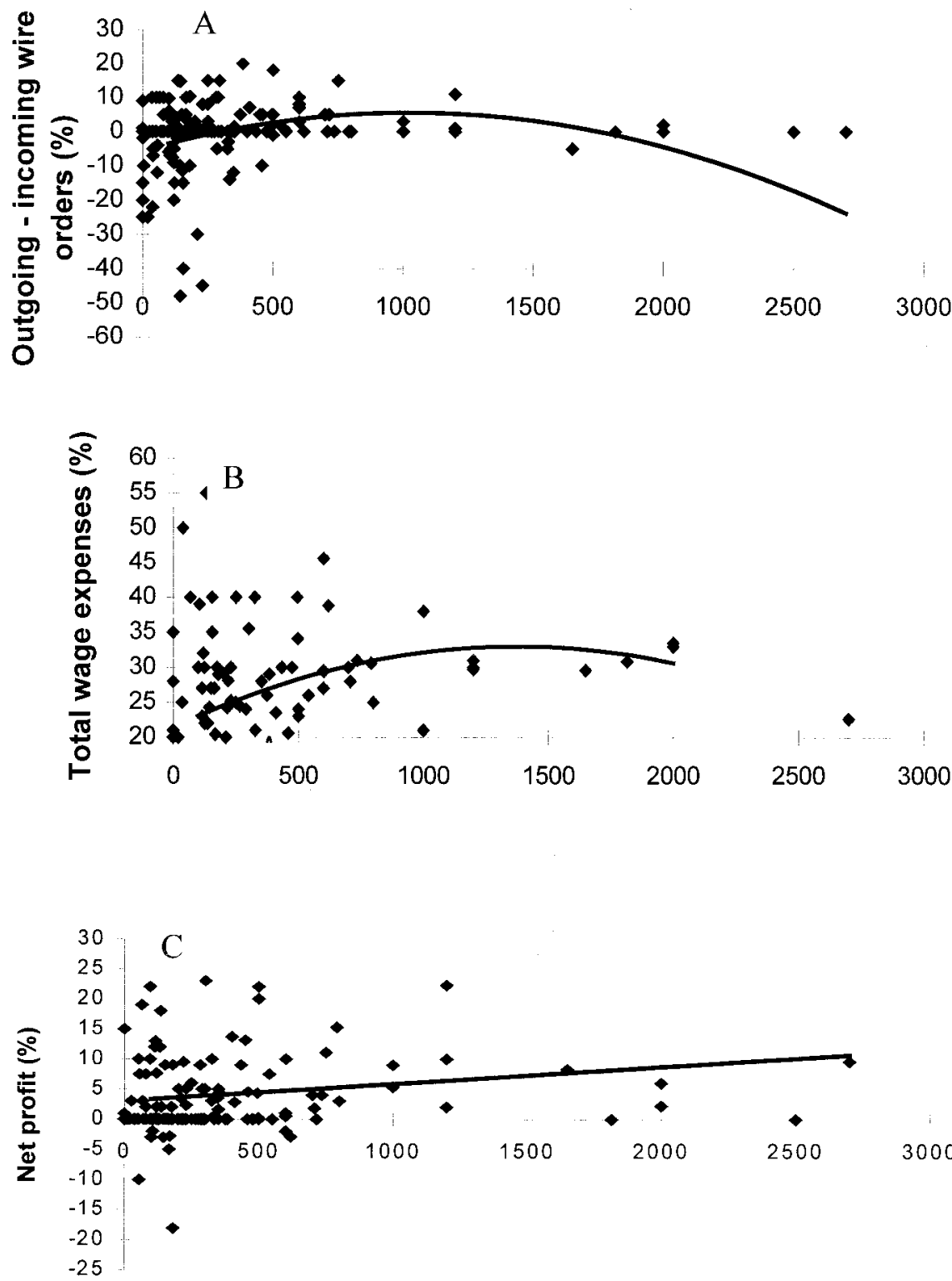

Annual gross sales (in $\$ 1000$ )

Fig. 1. Regression of (A) outgoing wire orders minus incoming wire orders (expressed as a percentage of annual gross sales) on annual gross sales $\left(\mathrm{y}=-5.555+21.651 s-10.516 s^{2}, r=0.255, P=0.034\right) ;(\mathbf{B})$ total wage expenses (expressed as a percentage of annual gross sales) on annual gross sales $(\mathrm{y}=21.393$ $+16.899 s-6.137 s^{2}, r=0.355, P=0.005$ ); and $(\mathbf{C})$ net profits (expressed as a percentage of annual gross sales) on annual gross sales $(\mathrm{y}=3.016+2.849 s, r=0.210, P=0.050)$. For scaling purposes, $s$ denotes annual gross sales in million dollars in regression equations. 
Significant differences among annual gross sales categories were found for mortgage and utilities costs (occupancy costs), total wage expense (owner and employees combined), professional memberships, store improvements, delivery vehicle expense, and net profits. Occupancy costs, as a percentage of annual gross sales, decreased as annual gross sales increased, even though the businesses with higher annual gross sales had larger stores. Total wage expense, as a percentage of annual gross sales, increased as annual gross sales increased, but businesses in the higher annual gross sales categories employed more people and generally paid them more. They also realized higher sales per employee. Regression indicated a significant quadratic relationship $(P=0.006)$ between total wages expense and annual gross sales (Fig. 1B). Total wages expense reached a maximum of $33.3 \%$ of annual gross sales when the latter rose to $\$ 1.4$ million. The variability of total wages expense was large, causing a small, yet significant, coefficient of determination. Delivery vehicle expense decreased with increasing annual gross sales. Businesses in the higher annual gross sales categories may have delivered more goods with the same quantity of inputs (vehicles, fuel, and maintenance) than businesses in the lower categories.

Net profits [annual sales revenue minus business expenses (both cash and non-cash) before taxes] increased with increasing annual gross sales $(1.7 \%$ low, $4.5 \%$ middle, $6.8 \%$ high). The significant $(P=0.05)$ linear regression of net profits on annual gross sales (Fig. 1C) predicted that for every $\$ 100,000$ increase in annual gross sales, there would be a corresponding $1.44 \%$ increase in net profits.

Further considerations. Labor and occupancy costs appeared to have the greatest effect on business health among the annual gross sales categories. Floral Finance (American Floral Services, 1997) recommends that total wages expense as a percentage of annual sales be kept $<30 \%$. For businesses in the highest annual gross sales category, total wages accounted for $29.8 \%$ of annual gross sales, whereas businesses in the lower two categories had total wages expenses of $23.0 \%$ and $26.4 \%$, respectively (Table 6 ). This trend of increasing labor costs at first does not appear to affect overall profitability, as businesses in the highest annual gross sales category still had the highest net profits. However, further insight into this trend was gained by calculating the total annual gross sales generated per dollar spent on owner and employee wages.

This value, calculated by using the reported annual gross sales figures and the total wage expense as a percentage of annual gross sales, declined as annual gross sales rose (Table 4) even though the businesses in each annual gross sales category met the Floral Finance guidelines on total wage expense. The value for the lowest annual gross sales category was significantly higher than the values for the higher two categories.

Businesses in the highest annual gross sales categories employed more people and paid them higher wages, but received significantly lower output per employee in return. Employees who are more highly trained and more productive deserve to be rewarded with higher wages. Businesses that set sales goals for their employees and monitor their outputs may be able to justify paying higher wages.

Respondents were asked to quantify the total area and the retail sales area of their businesses, and sales per square meter of total area and of retail sales area were calculated as a measure of business productivity. The total store area, retail sales area, and sales per square meter all increased with annual gross sales (Table 7). High volume stores required more space to function, but also used this space more productively. Michigan florist businesses were similar to the national averages for shop size and sales per square meter. Floral $\mathrm{Fi}$ nance (American Floral Services, 1996) reported a 1995 national mean of $1247 \mathrm{ft}^{2}(116$ $\mathrm{m}^{2}$ ) for retail sales area, with sales of $\$ 169$ per square foot ( $\$ 1819$ per square meter) of total shop space. The 1995 Michigan mean retail sales area was $1389 \mathrm{ft}^{2}\left(129 \mathrm{~m}^{2}\right)$, with sales of $\$ 134$ per square foot $(\$ 1442$ per square meter) of total shop space (Collins and Fails, 1996).

Occupancy costs (mortgage plus utilities expenses) as a percentage of annual gross sales decreased dramatically as annual gross sales increased (Table 6). This decreasing trend could account for the increasing trend in net profits. Floral Finance (American Floral Services, 1997) suggested that facilities ex-

Table 6. Comparison of mean full-service retail florist profits and losses by annual gross sales category (expressed as a percentage of annual gross sales).

\begin{tabular}{lccr}
\hline & \multicolumn{3}{c}{ Annual gross sales category } \\
\cline { 2 - 4 } Variable & $\$ 100,000$ to & $\$ 200,000$ to & $\begin{array}{c}\$ 400,000 \\
\text { and higher }\end{array}$ \\
\hline Cost of goods sold & 389.999 & $\$ 399,999$ & $38.1 \mathrm{a}$ \\
Mortgage or lease & $9.2 \mathrm{a}$ & $39.2 \mathrm{a}$ & $3.8 \mathrm{~b}$ \\
Utilities & $6.3 \mathrm{a}$ & $4.7 \mathrm{a}$ & $2.7 \mathrm{~b}$ \\
Occupancy costs-mortgage or lease plus utilities & $15.5 \mathrm{a}$ & $11.7 \mathrm{a}$ & $6.5 \mathrm{~b}$ \\
Employee wages & $15.6 \mathrm{~b}$ & $18.7 \mathrm{ab}$ & $23.1 \mathrm{a}$ \\
Owner salary or draw & $7.4 \mathrm{a}$ & $7.5 \mathrm{a}$ & $6.5 \mathrm{a}$ \\
Total wages - owner plus employee & $23.0 \mathrm{~b}$ & $26.4 \mathrm{ab}$ & $29.8 \mathrm{a}$ \\
Advertising and in-store promotion & $3.9 \mathrm{a}$ & $3.9 \mathrm{a}$ & $4.3 \mathrm{a}$ \\
Professional memberships, dues, subscriptions & $3.7 \mathrm{a}$ & $1.4 \mathrm{~b}$ & $1.7 \mathrm{~b}$ \\
Store equipment, improvements & $4.7 \mathrm{a}$ & $2.4 \mathrm{~b}$ & $2.8 \mathrm{~b}$ \\
Delivery vehicle expense & $6.0 \mathrm{a}$ & $4.5 \mathrm{ab}$ & $3.7 \mathrm{~b}$ \\
Other & $4.9 \mathrm{a}$ & $5.0 \mathrm{a}$ & $7.5 \mathrm{a}$ \\
Net profit or loss & $1.7 \mathrm{~b}$ & $4.5 \mathrm{ab}$ & $6.8 \mathrm{a}$ \\
\hline
\end{tabular}

${ }^{2}$ Mean separation within variables by Tukey's HSD, $P \leq 0.10$

Table 7. Comparison of mean full-service retail florist general business operations by annual gross sales category.

\begin{tabular}{lccc}
\hline \hline & \multicolumn{3}{c}{ Annual gross sales category } \\
\cline { 2 - 4 } Variable & $\$ 100,000$ to & $\$ 200,000$ to & $\begin{array}{c}\$ 400,000 \\
\text { and higher }\end{array}$ \\
\hline Total floor space $\left(\mathrm{m}^{2}\right)$ & $191 \mathrm{~b}^{2}$ & $249 \mathrm{~b}$ & $606 \mathrm{a}$ \\
Retail floor space $\left(\mathrm{m}^{2}\right)$ & $81 \mathrm{~b}$ & $118 \mathrm{~b}$ & $225 \mathrm{a}$ \\
Sales per $\mathrm{m}^{2}$ of total floor space & $\$ 1,195.22 \mathrm{~b}$ & $\$ 1,484.19 \mathrm{ab}$ & $\$ 2,212.51 \mathrm{a}$ \\
Sales per $\mathrm{m}^{2}$ of retail floor space & $\$ 3,031.39 \mathrm{~b}$ & $\$ 3,797.81 \mathrm{ab}$ & $\$ 7,431.48 \mathrm{a}$ \\
Occupancy cost per $\mathrm{m}^{2}$ of total floor space & $\$ 196.98 \mathrm{a}$ & $\$ 142.90 \mathrm{a}$ & $\$ 127.23 \mathrm{a}$
\end{tabular}

${ }^{2}$ Mean separation within variables by Tukey's HSD, $P \leq 0.10$. pense should not exceed $10 \%$ of annual sales, with $6 \%$ being optimum. Only businesses in the highest annual gross sales category achieved this optimum target for occupancy costs and had the highest level of net profits. The occupancy costs per square meter of total shop space did not differ significantly among the annual gross sales categories (Table 7). However, this information, coupled with the ncreasing trend in sales per square meter, showed that businesses in the higher sales categories were recouping this occupancy cost ensinesses may increase their net profits by lowering occupancy costs with the use of more energy-efficient appliances, the refinancing of mortgages, or the renegotiation of leases.

\section{Conclusion}

Full-service retail florists must examine and modify the cost structure of their businesses in order to generate the highest possible nesses are not very profitable, particularly given the number of hours most owners work the high level of competition. Florists have COGS as the primary indicator of financial health. This study chal. profitability. Many businesses a money on delivery because fees are not coverand the inherent business risk associated with 
ing costs. Stores that receive more incoming wire orders than they send are being hurt by wire service commissions and membership fees. Labor and occupancy costs play critical roles in determining retail florist profitability. Labor efficiency with respect to wages expense warrants further study, as it is the second largest business expense. With accessible, comprehensive business information and the ability to apply this knowledge to daily business operations, owners and managers of fullservice retail florist businesses may make sound business decisions with confidence.

\section{Literature Cited}

American Business Directories. 1995. Michigan business directory. Amer. Business Directories, Omaha, Nebr.

American Floral Services. 1996. 1996 Annual salary survey: Where do you stand? Floral Finance 15(5):3-8

American Floral Services. 1997. Know your numbers, they're important. Floral Finance 16(1):2.

Collins, C. and B. Fails. 1996. Michigan floral retailer business report. Michigan Floral Assn., Lansing.

Collins, C. and B. Fails. 1997. Are you losing money on deliveries? Floral Mgt. 13(12):39-43.
Dillman, D.A. 1978. Mail and telephone surveys: The total design method. Wiley-Interscience, New York.

Florists' Transworld Delivery Association. 1991. FTD flower business fact book. Florists' Transworld Delivery Assn., Southfield, Mich.

Redbook Florist Services Educational Advisory Committee. 1994. Retail flower shop operation. 2nd ed. Redbook Florist Serv., Paragould, Ark.

Teleflora. 1996. Floral industry trends. Flowers\& 17(1):88, 90.

Voigt, A.O. 1977. Business analysis of Pennsylvania retail florists. Pennsylvania State Univ., University Park. 